\title{
THE SMALL-SCALE DAIRY VALUE CHAIN ANALYSIS: CHALLENGES AND OPPORTUNITIES FOR DAIRY DEVELOPMENT IN MYMENSINGH DISTRICT OF BANGLADESH
}

\author{
H. Rahman ${ }^{1}$, F.A. Happy ${ }^{2 *}$, A.H. Efan ${ }^{1}$ and M.H.R. Hera ${ }^{3}$ \\ ${ }^{1}$ Department of Agribusiness and Marketing \\ ${ }^{2}$ Department of Agricultural Economics, Bangladesh Agricultural University \\ Mymensingh, Bangladesh \\ ${ }^{3}$ Plant Pathology Division, Bangladesh Rice Research Institute, Gazipur
}

\begin{abstract}
This study examined the prevailing dairy value chain based on primary data collected from 70 small-scale milk producers of Mymensingh district of Bangladesh. The total cost and net return per month per cow were Tk. 4024.30 and Tk. 3165.70, respectively. The net value additions of Tk. 2091.42, Tk. 495.00, Tk. 655.00, Tk. 503.25, Tk. 309.70 were estimated for milk producers, collectors, Faria, Bepari and retailers respectively. Different actors spent highest marketing cost ranged from Tk.49 to Tk.80 for transportation compared to other marketing functions. Actors mostly dependent on the on-going market prices for setting price of milk in the value chain. A value chain map was developed showing the relationships and linkages among value chain actors of small-scale dairy. The study identified some critical factors for successful dairy marketing. The factors were understanding consumer behaviour, technology and transportation, improved business relationships, reduced transaction costs, and improved information flow, and organized market structure. Milk producer's share in consumers' price was highest for channel- I followed by channel- V. Expensive, inadequate, low quality feed, lack of grazing land, green grass, inadequate capital, knowledge about cost of production, weak extension services, high fees and unavailability of veterinary doctors, were some of the major problems of milk producers. Supply of adequate feed at subsidized price, ensuring easy access to institutional credit at a lower interest rate, adequate medicine and veterinary services, allocation of khas land for producing fodder/grass, were suggested to solve the problems.
\end{abstract}

Keywords: Small-scale dairy, Value chain, Milk producer, Marketing

\footnotetext{
*Corresponding author: fardoushappy83@gmail.com
} 


\section{INTRODUCTION}

In all developed countries, dairy sector is receiving special attention from the government. It is because the milk and dairy products help building up vitally strong nations by developing brain and bone of its people. Dairy enterprise is considered as Treasure for the economy of Bangladesh, particularly for rural areas (Kabir and Talukder, 1999). In Bangladesh, the contribution of livestock sector to agriculture share of Gross Domestic Product was 13\% during 2014-15. Besides, according to FAO (2011), the per capita average yearly milk consumption in Bangladesh is only $13 \mathrm{~kg}$ and it is the lowest in South Asia because of higher cost of production and lower yield compared to any other south Asian countries. FAO statistics further reveals that the per capita daily calorie intake through milk in Bangladesh is only 24 Kcal, while in Sri Lanka it is 57, in Nepal it is 82, 104 in India, and 265 in Pakistan (FAO, 2011).

Rearing dairy cow is one of the most important investments a farmer can make to improve their socio-economic condition because of the valuable nutritional milk produced and diversify farming activities. It is estimated that more than 750 million people are engaged in milk production worldwide. The production of one million liters of milk per year on smallholder dairy farms creates approximately 200 on-farm jobs (ILRI, 2010). In Bangladesh, the annual national production of milk is 5.23 million tons and the annual demand is 17 million tons, out of which $97 \%$ is produced in rural areas. The quantity of national milk production can only meet about $30 \%$ of the actual demand for milk of the population (DLS, 2014).

Dairying is a biological system that converts large quantity of feeds and roughage into milk. It is more efficient and intensive system in terms of nutrient and protein production for human consumption from a given quantity of resources than beef or sheep farming (Michael, 1991). A farmer having not more than 10 cows will be fallen under small-scale category (DLS, 2014). However, small-scale dairying is very important for income generating activity to the poorer section of this country and reduction of the poverty. Traditionally, little attention has been paid to the value chains by which agricultural products reach final consumers and to the intrinsic potential of such chains to generate value added and employment opportunities (UNIDO, 2009).A value chain is a high-level model used to describe the process by which businesses receive raw materials, add value to the raw materials through various processes to create a finished product, and then sell the end product to customers (Porter and Michael, 1985). The livestock value chain can be defined as the full range of activities required to bring product (e.g. live animals, meat, milk, eggs, leather, fiber, manure) to final consumers passing through different phases of production, processing and delivery. Value chain analysis is essential to an understanding of markets, their relationships, the participation of different actors, and the critical constraints. The development of the dairy sector in the country is hindered by a number of technical, institutional and socioeconomic constraints. Development 
of small scale dairy sector through the assessment of dairy market is necessary to create employment opportunity for the people in rural areas.

Modalities of such impact have been described in a good number of literatures. An attempt has been made in this section to review the previous studies related to the present study. Kabir and Talukder (1999) examined the financial performance of small scale dairy farms participating in the government subsidy programme. Significant increase in production and consumption of milk as well as in labor employment was observed. Shamsuddoha (2000) carried out a study on problems and prospects of dairy industry in Bangladesh. He described the main problems concerning feeding, management, diseases and marketing for which dairy development is unsatisfactory. O'Lakes (2010) carried out a study on dairy value chains, end markets and food security for Ethiopia. A majority of the dairy households in Ethiopia directly consume most of their animals' milk production $(85 \%)$ and the informal market channel handles $90 \%$ of milk and milk products. Achchuthan and Kajananthan (2012) conducted a study on the value chain analysis in dairy sector in Kilinochchi District, Sri Lanka. Weindmailer (2003) investigated the milk value chain: concept, possibilities of optimization and areas of conflict. The importance of supply chain for the milk value chain and its effect on consumer response are discussed. Mandal (2006) carried out a study on supply chain analysis of wholesale milk market in selected areas of Dhaka district. The study also revealed that the value addition of sweet meat shop owners were higher than that of other intermediaries. Seifu and Doluschitz (2014) conducted a study to characterize the dairy value chain and to identify challenges and opportunities for development of the dairy industry in Dire Dawa, Eastern Ethiopia.

More study was conducted on the value chain of commercial dairy farmers and other agricultural products. There was no study on value chain of small scale dairy farmers living in rural areas that provides lion's share of milk to the consumers in the country. The milk yield, reproductive performance of cows, the transformation, marketing and final sale of the dairy products to consumers does not reach their full potential because of various challenges associated with each value chain actors that need to be identified. Therefore, the present study was aimed identify the key actors, map the value chain and emerging challenges in dairy production.

\section{MATERIALS AND METHODS}

The study was conducted in at three Upazilas namely Gafargaon, Bhaluka and Trishal under Mymensingh district where different market actors were available. A total of 30 milk producers and 40 traders were selected as sample. Among the traders, milk collector, Faria, Bepari and retailer were 10 individually in number. Market actors were interviewed using structured interview schedule for collection of data and information through face-to-face interview method. 


\section{Analytical Techniques}

Descriptive statistics were used to analyse key actors with functions and the value chain map of small scale dairy farmer.

\section{Measurement of value addition}

To achieve the third objective of the study, the following equation was used to assess the profitability of milk producers and value addition by traders.

i) Net Return of milk producer

$$
\Pi=\sum_{i=1}^{n}\left(P_{Y_{i}} \cdot Y_{i}\right)-\sum_{i=1}^{n}\left(P_{X_{i}} \cdot X_{i}\right)-T F C
$$

Where,

$\Pi=$ Profit of producers per month per quintal of milk;

$P_{Y_{i}}=$ Per unit price of milk (Tk./litre);

$Y_{i}=$ Quantity of milk (litre/day);

$P_{X_{i}}=$ Per unit price of i-th input (Tk.);

$X_{i}=$ Quantity of i-th input per day per cow $(\mathrm{kg})$;

TFC $=$ Total fixed costs $(\mathrm{Tk}$.$) ; and$

$\mathrm{i}=1,2,3 \ldots, \mathrm{n}$ (number of items).

Value addition by an independent farmer= Selling price - Production cost

Value addition by the traders=Selling price - Purchase price

Net value addition by independent farmers or traders =Value addition - Marketing cost

Actor's share in consumers' price

Farmer's share in consumer's price $=$ (Farmer's selling price/Consumer's purchasing price)*100

Wholesaler's share in consumer's price $=$ (Total market margin of wholesalers/Consumer's purchasing price)*100

Retailer's share in consumer's price $=$ (Total market margin of retailers/Consumer's purchasing price)*100

\section{Measurement of milk marketing efficiency}

There are several types of measures that have some values and limitations in measuring marketing efficiency, but no single one can tell the whole story. However, the following formula was used to measure the milk marketing efficiency (Acharya and Agarwal, 
2004) of a particular marketing chain. The higher value of marketing efficiency denotes higher level of efficiency and vice versa.

Marketing efficiency $(\mathrm{ME})=\frac{F P}{M C+M M}$

Where,

$\mathrm{FP}=$ Net price received by producer $(\mathrm{Tk} / \mathrm{ton})$

$\mathrm{MC}=$ Total marketing cost incurred by intermediaries (Tk/ton)

$\mathrm{MM}=$ Total net marketing margin received by intermediaries (Tk/ton)

\section{SWOT Analysis}

ASWOT analysis was done in this study which identified the internal and external factors that are favorable and unfavorable to small-scale dairy sector. A SWOT analysis is usually in the form of a $2 \times 2$ matrix or a grid with four sections. The top two sections list the strengths and weaknesses and the lower two sections list the opportunities and threats.

\section{RESULTS AND DISCUSSION \\ Marketing Functions of Small Scale Dairy Value Chain Actors \\ Buying and selling}

Small scale dairy farmers sold $60 \%$ of their milk to collector and Faria and the remaining $40 \%$ sold to the consumers directly. About $30 \%$ of milk was sold to the Bepari by collectors and $70 \%$ to Faria. Faria sold $75 \%$ of milk to Bepari, $18 \%$ to consumer and $7 \%$ to retailer. Bepari sold $27 \%$ of milk to the local retailers at Upazila level and rest to the district level buyers. Finally, retailer sold their milk to the ultimate consumers (Field survey, 2017).

\section{Pricing practices, market information and financing}

Most of the farmers $(80 \%)$ and collectors $(60 \%)$ practiced on-going market price; Faria $(70 \%)$ and retailer $(60 \%)$ followed open bargaining and Bepari $(80 \%)$ practiced prefixed prices for selling milk to different market actors (Table 1). Farmers (80\%), collectors (70\%), Faria (80\%), Bepari (75\%) and retailer (90\%) got most of their market information from milk market and the rest was from other traders. The main financial source for farmers (70\%), collectors $(85 \%)$, Faria $(75 \%)$, Bepari $(40 \%)$ and retailers $(70 \%)$ was own fund to run dairy business. They also borrowed little amount of money from bank, NGO, friends and relatives. Different mode of transportation like van, rickshaw, bus, bicycle, pickup, and train was used to transfer milk to market actors. Farmer did not use train, collector did not use van and rickshaw, and Faria did not use rickshaw. Bepari only use pickup and train. Consumers directly buy milk from producers, Faria or retailers (Table 1). 
Table 1. Price fixing, market information, sources of finance and mode of transportation of dairy value chain actors

\begin{tabular}{lccccc}
\hline \multicolumn{1}{c}{ Particulars } & \multicolumn{5}{c}{ Percent of responses } \\
\hline A. Price fixing strategies & Farmer & Collector & Faria & Bepari & Retailer \\
Open bargaining & 0 & 30 & 70 & 0 & 60 \\
Based on-going market price & 80 & 60 & 30 & 20 & 40 \\
$\quad$ Prefixed price & 20 & 10 & -- & 80 & -- \\
B. Market information & & & & & \\
sources & & & & & \\
$\quad$ Collect information from & 80 & 70 & 80 & 75 & 90 \\
$\quad$ market & 20 & 30 & 20 & 25 & 10 \\
Other traders & & & & & \\
C. Financial sources & 70 & 85 & 75 & 40 & 70 \\
Own fund & 15 & -- & 5 & 30 & 7 \\
Bank & 10 & 5 & 15 & 20 & 8 \\
NGO & 5 & 10 & 5 & 10 & 15 \\
Friends and relatives & & & & & \\
D. Mode of transportation & 20 & -- & 5 & -- & -- \\
$\quad$ Van & 2 & -- & -- & -- & -- \\
Rickshaw & 10 & 30 & 10 & -- & -- \\
Bus & 8 & 40 & 20 & -- & -- \\
Bicycle & 10 & 20 & 40 & 50 & -- \\
Pickup & - & 10 & 25 & 30 & -- \\
Train & 50 & -- & -- & 20 & -- \\
Others & & & & & \\
\hline
\end{tabular}

Source: Field survey, 2017

\section{Packaging}

Polythene or plastic bottle was used for packaging by farmer and retailer, large metal drums were used by Bepari for milk transportation. They used banana leaf to reduce perishability of milk.

\section{Dairy Value Chain Governance}

In the study area, most farmers feed low quality feed to cows and try to earn more profit by mixing water with milk. The marketing of milk was conducted following traditional rules and regulations. 


\section{Mapping of Small-scale Dairy Value Chain and Critical Success Factors of Value Chain}

\section{Mapping value chain of small scale diary}

Value chain of dairy started from dairy producer then collector, Faria, Bepari and finally retailer who added value to the marketing channel of milk.

Channel I: Farmer $\rightarrow$ Local Consumer (home delivery)

Channel II: Farmer $\rightarrow$ Collector $\rightarrow$ Bepari $\rightarrow$ Retailer $\rightarrow$ Consumer

Channel III: Farmer $\rightarrow$ Bepari $\rightarrow$ Retailer $\rightarrow$ Consumer

Channel IV: Farmer $\rightarrow$ Collector $\rightarrow$ Faria $\rightarrow$ Bepari $\rightarrow$ Retailer $\rightarrow$ Consumer

Channel V: Farmer $\rightarrow$ Collector $\rightarrow$ Faria $\rightarrow$ Consumer

Channel VI: Farmer $\rightarrow$ Collector $\rightarrow$ Faria $\rightarrow$ Retailer $\rightarrow$ Consumer

Small scale producer utilized milk by home consumption and selling. When milk is transferred to wholesalers (Collector, Faria, Bepari), they either sell it to retailers or traditional processors (who make sweet and curd) or to distant larger wholesale market (Mymensingh, Dhaka, and Gazipur) for urban consumers. In figure 5.1, the distribution channel, actors involved in milk business and their percentage of net value addition was shown.

\section{The Critical Success Factors of Dairy Value Chain}

Henry Ford reported that "coming together is a beginning. Keeping together is progress. Working together is success" (Brainy Quote, 2005). The key success factors are discussed below:

\section{Understanding Consumer Behavior Properly}

The actors fail to anticipate the market demand for milk due to less education and less awareness of changing consumer behaviour.

\section{Technology and Transportation}

The major technological constraint was the absent of processing plant. About $50 \%$ of the farmers and $75 \%$ of the traders opined that the transportation system of milk marketing was good.

\section{Improved Business Relationships}

Gooch observed that respect, not trust, is one of the fundamental pillars upon which many successful agro-food value chains are founded. According to the survey, $30 \%$ of the respondent actors complained adopting unethical activities like mixing water and powder milk with liquid milk that hampers the dairy business of others. 


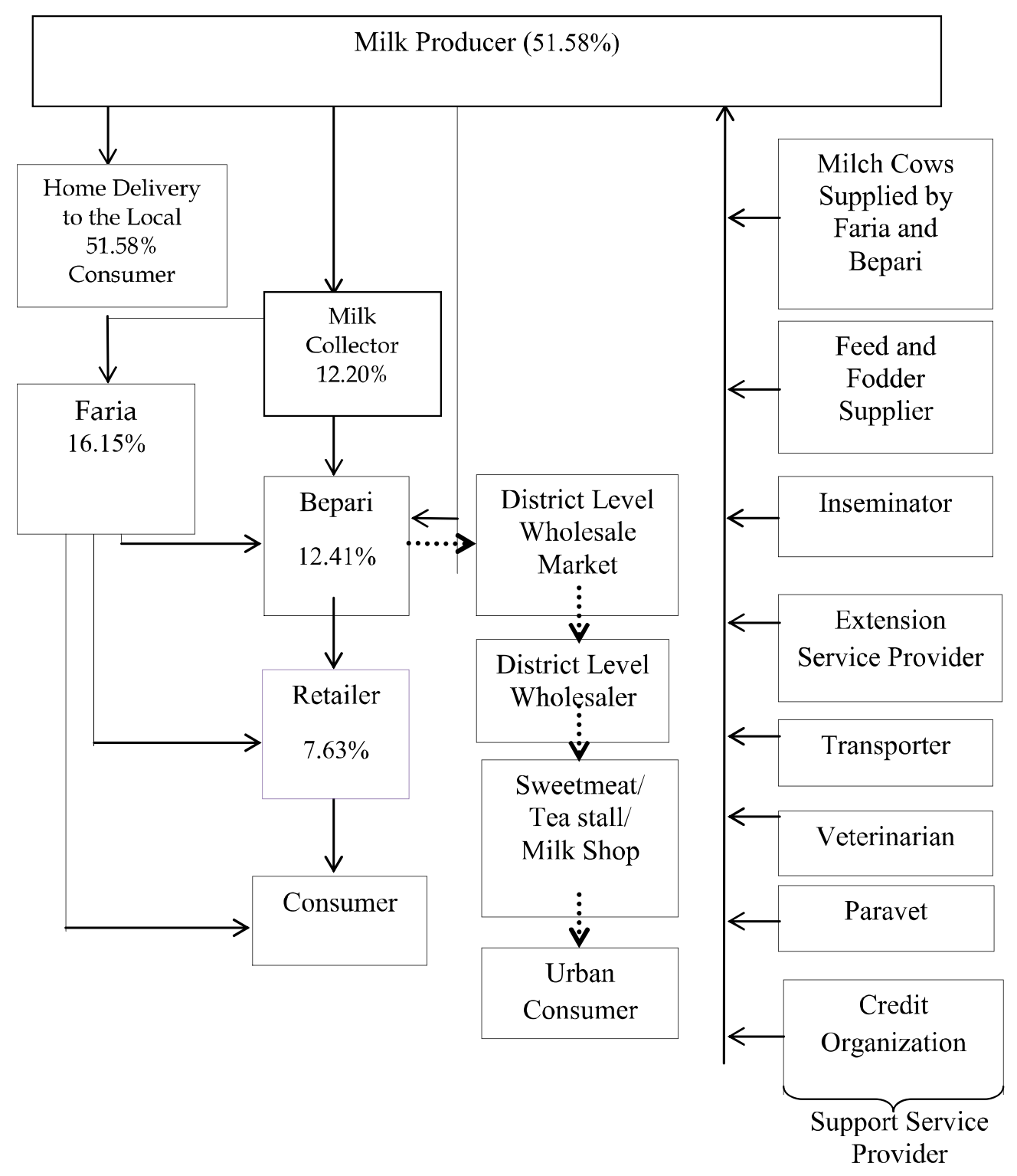

Note: Dotted line represents the local dairy value chain and Straight line represents overall small scale dairy value chain in the selected areas. $\%=$ Total value addition

Source: Field survey, 2017

Figure 1. Mapping the relationships and linkages between value chain actors of small scale dairy 


\section{Reduced Transaction Costs}

Hobbs (1996) categorized transaction costs into three types. These are information costs, negotiation costs, and monitoring costs. In small-scale dairy value chain while prices are often the main focus of commodity there was no attempt to reduce the transaction costs.

\section{Improved Information Flow}

About $30 \%$ of the dairy actors opined that they didn't have enough access to accurate, timely and relevant information which increases transaction costs and results in inappropriate resource allocation.

\section{Organized Market Structure}

Small-scale dairy market is not well organized due to no fixed chain and price fluctuation hampers efficiency of value chain stated by $20 \%$ actors.

\section{Governance}

The was no market monitoring authorities opined by $65 \%$ actors to control the price variation; maintain quality feed, and healthy handle of bulk milk.

\section{Cost, Return and Value Addition Analysis}

\section{Production cost and return of dairy}

For calculating total production cost, both variable and fixed costs were taken into consideration. The components of variable cost were the feed cost (paddy straw, green grass, oil cake, molasses, bran and salt), labour cost, doctor cost, medicine cost, interest on operating capital and miscellaneous cost. Fixed cost items for milk production were land use cost, cowshed and maintenance cost. It is evident that total variable cost and fixed cost of milk production was Tk. 3715.02 and Tk. 309.28 per month per cow which was $92 \%$ and $8 \%$ of total cost. Among variable components, feed incurred the highest cost $(79.13 \%$ of total cost) followed by interest on operating capital $(5.53 \%)$ and labour. Net margin per quintal of milk was Tk. 2638.08 (Table 2).

Table 2. Total cost and return for small-scale dairy farming

\begin{tabular}{lcc}
\hline Particulars & Tk. /month/cow & Percent of total \\
\hline 1.Variable cost & Production cost \\
A.Feed cost & $\mathbf{3 7 1 5 . 0 2}$ & $\mathbf{9 2 . 3 1}$ \\
Paddy straw & 3184.6 & 79.13 \\
Green grass & 219.3 & 5.45 \\
Oil cake & 988.9 & 24.58 \\
Molasses & 287.5 & 7.14 \\
& 264.3 & 6.56
\end{tabular}




\begin{tabular}{|c|c|c|c|c|c|}
\hline \multicolumn{3}{|l|}{ Particulars } & Tk. /month/cow & \multicolumn{2}{|c|}{ Percent of total } \\
\hline \multicolumn{3}{|l|}{ Bran } & 1080.0 & \multicolumn{2}{|c|}{26.83} \\
\hline \multicolumn{3}{|l|}{ Salt } & 216.6 & \multicolumn{2}{|c|}{5.38} \\
\hline \multicolumn{3}{|c|}{ B. Labour cost } & 166.66 & \multicolumn{2}{|c|}{4.14} \\
\hline \multicolumn{3}{|c|}{ C. Doctor cost } & 31.25 & \multicolumn{2}{|c|}{0.77} \\
\hline \multicolumn{3}{|c|}{ D. Medicine cost } & 104.16 & \multicolumn{2}{|c|}{2.58} \\
\hline \multicolumn{3}{|c|}{ E. Interest on operating capital } & 222.756 & \multicolumn{2}{|c|}{5.53} \\
\hline \multicolumn{3}{|c|}{ F. Miscellaneous cost } & 5.60 & \multicolumn{2}{|c|}{0.13} \\
\hline \multicolumn{3}{|c|}{ 2.Fixed cost } & 309.28 & \multicolumn{2}{|c|}{7.68} \\
\hline \multicolumn{3}{|c|}{ A. Land use cost } & 186.4 & \multicolumn{2}{|c|}{4.63} \\
\hline \multicolumn{3}{|c|}{ B. Cowshed and maintenance } & 122.88 & \multicolumn{2}{|c|}{3.05} \\
\hline \multicolumn{3}{|c|}{ Total cost $(\mathrm{Tk} . / \mathrm{month} / \mathrm{cow})(1+2)$} & 4024.30 & \multicolumn{2}{|c|}{100} \\
\hline \multicolumn{3}{|c|}{ Total cost (Tk./100 Litre) } & 3353.58 & \multicolumn{2}{|c|}{-} \\
\hline \multicolumn{6}{|c|}{ Gross return of per month per dairy cow } \\
\hline Particulars & Unit & Amount & Price/unit & $\begin{array}{c}\text { Gross return } \\
\text { (Tk/month) }\end{array}$ & $\begin{array}{l}\text { Percent } \\
\text { of total }\end{array}$ \\
\hline Milk & Litre & 120 & 50 & 6000 & 83.46 \\
\hline Cow dung & $\mathrm{Kg}$ & 180 & 2 & 360 & 5 \\
\hline Calf & - & - & - & 830 & 11.54 \\
\hline Total & & & & 7190 & 100 \\
\hline
\end{tabular}

\begin{tabular}{lc}
\hline \multicolumn{1}{c}{ Gross margin and net return per month per dairy cow } \\
\hline Particulars & Amount per month \\
\hline a. Gross return & 7190 \\
b. Variable cost & 3715.02 \\
c. Total cost & 4024.30 \\
d. Gross margin (a-b) & 3474.98 \\
e. Net margin (a-c) & 3165.7 \\
Net margin per 100 litre of milk (Tk.) & 2638.08 \\
Source: Field survey, 2017 & \\
\hline
\end{tabular}

\section{Marketing Cost and Value Addition}

Different items were associated with marketing cost of milk. The major marketing cost for milk producer was packing of milk with poly bag $(48.40 \%)$. On the other hand, milk collector, Faria, and Bepari incurred the highest cost for transportation $(47.62 \%, 55.17 \%$ and $50.40 \%)$ as a part of marketing cost. Milk retailer spent larger 
portion of total cost for paying rent. Among different marketing actors, the highest cost was incurred by milk producers (Tk. 155/100 litre) followed by Faria (Tk.145) and milk collector. Total value addition and net value addition were highest for milk producer (Tk. 2246.42 and Tk. 2091.42 per 100 litre) compared to other marketing actors (Table 3).

Table 3: Marketing cost and value addition by different marketing actors of dairy value chain

\begin{tabular}{|c|c|c|c|c|c|}
\hline \multirow[t]{2}{*}{ Particulars } & \multicolumn{5}{|c|}{ Tk. per 100 litre of milk } \\
\hline & Milk producer & Milk collector & Faria & Bepari & Retailer \\
\hline \multicolumn{6}{|l|}{ Marketing cost items } \\
\hline Poly bags & 75 & - & - & - & - \\
\hline Transportation & 60 & 50 & 80 & 48.75 & - \\
\hline Milk container & 20 & 15 & 15 & 0.50 & - \\
\hline $\begin{array}{l}\text { Others (spoilage, gift, } \\
\text { grant) }\end{array}$ & - & 20 & 20 & 5 & 5 \\
\hline Personal expenses & - & 20 & 30 & 20 & - \\
\hline Labour & - & - & - & 17.50 & - \\
\hline Market toll & - & - & - & 5 & 4 \\
\hline Rent & - & - & - & - & 50 \\
\hline Electricity & - & - & - & - & 11.30 \\
\hline Plastic bottle & - & - & - & - & 20 \\
\hline Total marketing cost & 155 & 105 & 145 & 96.75 & 90.3 \\
\hline \multicolumn{6}{|l|}{ Value addition items } \\
\hline $\begin{array}{ll}\text { a. Production } \\
\text { cost/Purchasing price }\end{array}$ & 3353.58 & 5000 & 5600 & 6400 & 6600 \\
\hline b. Marketing cost & 155 & 105 & 145 & 96.75 & 90.3 \\
\hline c. Selling price & 5600 & 5600 & 6400 & 6600 & 6800 \\
\hline d. Total value addition (c-a) & 2246.42 & 600 & 800 & 600 & 400 \\
\hline e. Net value addition (d-b) & 2091.42 & 495 & 655 & 503.25 & 309.7 \\
\hline f. Total value addition (\%) & 51.58 & 12.20 & 16.15 & 12.41 & 7.63 \\
\hline
\end{tabular}

Source: Field survey, 2017.

Note: For direct selling producers got Tk.56/litre of milk

Table 4 shows that milk producer's share in consumers' price was highest for channel- I and second highest for channel- V. Wholesaler's share in consumers' price was highest for channel- II, III, IV, and retailer's share in consumers' price was 
highest for channel- VI. On the other hand, channel was ranked on the basis of marketing efficiency; the first and last ranked channel was channel I and channels VI.

Table 4. Actor's share in consumers' price and marketing efficiency of small scale dairy value chain

\begin{tabular}{l|c|c|c|c|c}
\hline Channel & $\begin{array}{c}\text { Milk producer's } \\
\text { share in } \\
\text { consumers' price }\end{array}$ & $\begin{array}{c}\text { Wholesaler's } \\
\text { share in } \\
\text { consumers' price }\end{array}$ & $\begin{array}{c}\text { Retailer's share } \\
\text { in consumers' } \\
\text { price }\end{array}$ & $\begin{array}{c}\text { Marketing } \\
\text { efficiency } \\
\text { (ME) }\end{array}$ & $\begin{array}{c}\text { Channel } \\
\text { Ranking(On the } \\
\text { basis of ME) }\end{array}$ \\
\hline Channel I & 100 & - & - & 5.02 & 1 \\
Channel II & 82.35 & 14.71 & 2.94 & 4.13 & 5 \\
Channel III & 82.35 & 14.71 & 2.94 & 4.41 & 3 \\
Channel IV & 82.35 & 14.71 & 2.94 & 3.79 & 2 \\
Channel V & 87.50 & 12.50 & - & 4.24 & 4 \\
Channel VI & 82.35 & 11.76 & 5.88 & 4.01 & 6 \\
\hline
\end{tabular}

Source: Field survey, 2017.

\section{Challenges and Opportunities for Dairy Production and Marketing}

The weaknesses and threats of the small-scale dairy sector were more or less to all the sample farmers under the present study. Strengths and opportunities of this sector were similar too to the compatibilities of the small-scale dairy sector of these areas (Table 5).

Table 5. SWOT analysis of the small-scale dairy sector

\begin{tabular}{|c|c|}
\hline Strengths & Weaknesses \\
\hline $\begin{array}{l}\text { - Large cattle population reared by vast } \\
\text { rural population. } \\
\text { - Growing milk demand in urban areas } \\
\text { for changing life style due to education } \\
\text { and income. } \\
\text { - Availability of Khas, Char and high } \\
\text { lands for pasturing cows. } \\
\text { - Lower price of forage compared to } \\
\text { other feeds. } \\
\text { Well communication among marketing } \\
\text { actors. }\end{array}$ & $\begin{array}{l}\text { - Limited supply, poor quality and } \\
\text { higher price of feed. } \\
\text { - Mostly reared local breed cows. } \\
\text { - Absence of quality control and } \\
\text { improved milk production technology. } \\
\text { - Absence of farmer's consciousness, } \\
\text { animal husbandry and nutrition } \\
\text { strategies. } \\
\text { Shortage of skilled and trained } \\
\text { technical staff. } \\
\text { Insufficient artificial insemination } \\
\text { facilities. } \\
\text { Lack of milk collection centers, dairy } \\
\text { cooperatives and milk processing plant. }\end{array}$ \\
\hline
\end{tabular}




\begin{tabular}{|c|c|}
\hline Strengths & Weaknesses \\
\hline & $\begin{array}{l}\text { - } \text { Existing cultural indifferences milk is } \\
\text { for children and the sick people. } \\
\text { - Lack of reliable and up-to-date } \\
\text { information. }\end{array}$ \\
\hline Opportunities & Threats \\
\hline $\begin{array}{l}\text { - Increased demand for milk in various } \\
\text { forms. } \\
\text { Institutional market segments (such as } \\
\text { hotels, hospitals, schools and } \\
\text { universities) for dairy and dairy } \\
\text { products are available. } \\
\text { - Existence of political stability and } \\
\text { conducive investment climate. } \\
\text { - Undeveloped and low competition } \\
\text { among producers. } \\
\text { Access to well-developed train and } \\
\text { road transport systems. }\end{array}$ & $\begin{array}{l}\text { - Shortage of green grass during natural } \\
\text { disaster. } \\
\text { - Higher prices of improved breeds. } \\
\text { - Weak financial base of the small scale } \\
\text { dairy farmers. } \\
\text { - Loss of milk due to perishable nature. } \\
\text { - Unequal demand during rainy season } \\
\text { and fasting period (month of } \\
\text { Ramadan). }\end{array}$ \\
\hline
\end{tabular}

Source: Field survey, 2017.

\section{CONCLUSIONS}

The significance of dairy value chain analysis at small-scale is high as dairy sector is the means of livelihood of a large number of small farmers and traders; and it provides lion's share of the protein to the population of Bangladesh. It is found that dairy farming is profitable at small scale. The net value addition is positive and high at each level and profitable for traders. Farmers contributed to the highest value addition and Faria was the second highest contributor for their different services among all the actors of the value chain. Farmers and collectors practiced mostly ongoing market price; Faria and retailer followed open bargaining and Bepari dependent on prefixed price for selling milk. Milk producer's share in consumers' price was highest in different channel. The highest share of marketing cost for milk producer was packing of milk which needs to be reduced for lowering cost of milk. Again, milk collector, Faria, and Bepari incurred the highest cost for transportation. There are both challenges and opportunities exist in the dairy sector.

\section{REFERENCES}

Acharya, S.S. and Agarwal, N.L. (2004). Agricultural Marketing in India (4th Edition), Oxford and IBH Publishing Co. Pvt. Ltd., New Delhi, India.

Achchuthan, S. and Kajananthan, R. (2012). A Study on Value Chain Analysis in Dairy Sector Kilinochchi District, Sri Lanka. Global Journal of Management and Business Research 12 Issue 21 Version 1.0. 
DLS (2014): Department of Livestock Services, An overview, DLS, Dhaka, Bangladesh.

FAOSTAT (2011): Food and Agricultural Organization of the United Nations, Statistical database FAO, Rome, Italy. Retrieved from <http: //faostat.fao.org/>. (Accessed on 30 April 2017.)

Hobbs, J. (1996). A Transaction Cost Approach to Supply Chain Management. International Journal of Supply Chain Management 1(2): 15-27.

ILRI (2010). FAO action program for the prevention of food loses. Milk and dairy products, post-harvest loses and food safety in sub-Saharan Africa and the near east. Regional approaches to national challenges. Synthesis report ILRI, Nairobi, Kenya.

Kabir, M.H. and Talukder, R.K. (1999). Economics of small-scale dairy farming in Bangladesh under the government support programme. Asian-Australian Journal of Animal Science, 12 (3),429-434.

Land O'Lakes (2010). The Next Stage in Dairy Development, Dairy Value Chains, End Markets and Food Security. Land O'Lakes, Inc, IDD. Addis Ababa, Ethiopia.

Mandal, A.K. (2006). Supply Chain Analysis of Wholesale Milk Market in Selected Areas of Dhaka District. M.S. Thesis, Department of Co-operation and Marketing, Bangladesh Agricultural University, Mymensingh.

Michael, J. (1991). "Dairy Development in Sub-Saharan African-A study of issues and options", World Bank Technical paper, Number 135, The World Bank, Washington, D.C., U.S.A. cited from pandit 1993.

O'Lakes, L. (2010). The next stage in dairy development for Ethiopia: Dairy Value Chains, End Markets and Food Security. Cooperative agreement 663-a-00-05-00431-00. USAID and Land O'Lakes. Addis Ababa, Ethiopia.

Porter, M. and Michael, E. (1985). Competitive Advantage. The Free Press, New York. pp.11-15.

Shamsuddoha, A.K. and Edwards, G. (2000). Dairy Industry in Bangladesh: Problems and Prospects. Paper for AARES 2000 Conference, Dhaka-1209, March 20, 2000.

Seifu, E. and Doluschitz, R. (2014). Analysis of the dairy value chain: Challenges and opportunities for dairy development in Dire Dawa, Eastern Ethiopia. International Journal of Agricultural Policy and Research, 2(6): 224-233.

UNIDO. (2009). United Nations Industrial Development Organization, Annual Report 2009 UNIDO, Vienna, Austria.

Weindlmaier, H. (2003). The milk value chain. Concept, possibilities of optimization and areas of conflict. Deutche Milk chwirts chaft, 54(3): 109-111. 